\title{
Describing Sexual Dimorphism in Inner Wings of Brontispa longissima Using Landmark Based Geometric Morphometric Analysis
}

\author{
Bryan George D. Belleza and Cesar G. Demayo
}

\begin{abstract}
Sexual dimorphism is a widespread phenomenon among groups of animals that describe variation in morphology between individuals of different sexes. Differences in wing shape morphology among sexes of the same species of insects often reflects disparity in flight performance and flight range which might be of considerable significance in the monitoring and control of pest species. This study was conducted to determine the differences in wing morphology between sexes of coconut hispid beetle (Brontispa longissima) by looking at the variations in the shapes of the entire wing using geometric morphometrics. The results obtained showed noticeable variation in the left and right inner wings between female and male samples as shown in the relative warp analysis. Discriminant function analysis, MANOVA/CVA scores, and Kruskal-Wallis test showed statistically significant variation between sexes establishing the presence of sexual dimorphism within the species of coconut hispid beetles.
\end{abstract}

Index Terms-B. longissima, geometric morphometrics, sexual dimorphism, wing morphology.

\section{INTRODUCTION}

Sexual dimorphism, defined as the variation in morphology between individuals of different sexes that belongs to the same species, is a widespread phenomenon among different groups of animals [1]. It has been considered as one of the most interesting sources of phenotypic variation among organisms and has become an increasingly important area of study in evolutionary biology [2]. The direction of the differences is, whether, males or females are larger or they differ in distinctive groups [3].

Insect wings, one of the most important organs of insects, have large contribution to them to become the most prosperous biological community. Wing shape morphology using geometric morphometrics has been extensively studied in the field of entomology to clarify the relationship between closely related taxa and to help in identifying population within and between species of insects. In recent years, more attention has been paid to morphometric approaches, due to new methods of analysis such as geometric morphology [4]-[6]. These methods allow the study of form without the effects of scale, rotation and translation of objects, thus they

\footnotetext{
Manuscript received March 3, 2014; revised May 5, 2014. This work was supported in part by the Department of Science and Technology Accelerated Science and Technology Human Resource Development Program (DOST-ASTHRDP).

The authors are with the Department of Biological Sciences, College of Science and Mathematics, MSU - Iligan Institute of Technology, Iligan City, Philippines (e-mail: bryangeorge.belleza@gmail.com, cgdemayo@gmail.com). .
}

have a better biological interpretation and are a graphical tool for visualization and quantification of morphological variation in different ecological and evolutionary contexts [7], [8].

Coconut Hispid Beetle (Brontispa longissima) is worthy of being investigated for wing shape variation since it is considered to be a serious pest that has greatly affected the coconut industry [9]. It has been suggested that the wing of $B$. longissima might be considered as an ontogenetically modular structure primarily divided into different compartments which is a considerable evidence indicating difference in wing morphology [10]. By quantifying morphological variation, this could contribute to easier identification in the relationship between morphology and ecology which furthermore can serve more informed deduction on species' evolution [11]. Differences in wing morphology between sexes of the same species of insects often reflect disparity in flight performance and flight range which might be of considerable significance in the monitoring and control of pest species [1]. Hence, this study was conducted to describe and determine the presence of sexual dimorphism in different populations of B. longissima based on the shape variation of its inner wings.

\section{Methodology}

\section{A. Sample Collection and Processing}

Coconut Hispid Beetle (Brontispa longissima) sample were collected from three different provinces in the Philippines: Aloran, Misamis Occidental, Calube, Zamboanga del Norte and San Vicente, Butuan City. Specimens were placed in properly labeled containers filled with $70 \%$ ethanol. Sex of samples was identified through visual inspection of the genitalia under a stereo microscope.

The inner wings were detached and were mounted neatly in clean and clear glass slides and were properly labeled. Digital images were captured using Olympus E-410 DSLR Camera attached on a Leica Stereomicroscope.

\section{B. Organizing and Digitalization}

Inner wings were grouped according to sex (male and female) and divided separately (left wing and right wing) in different provinces. Triplicate of an image was made to insure consistency. The images of grouped samples were digitized using tpsUtil [12] and saved as thin-plate splines (TPS) files.

\section{Landmark Selection}

Landmarks together with pseudolandmarks were assigned 
to the prominent features in the inner wings of B. longissima. A total of seventeen (17) landmarks were chosen on the left and right inner wings for their capacity to define the major elements of shape and for their reliability as homologous structure (Fig. 1). The chosen landmarks are described in Table I.

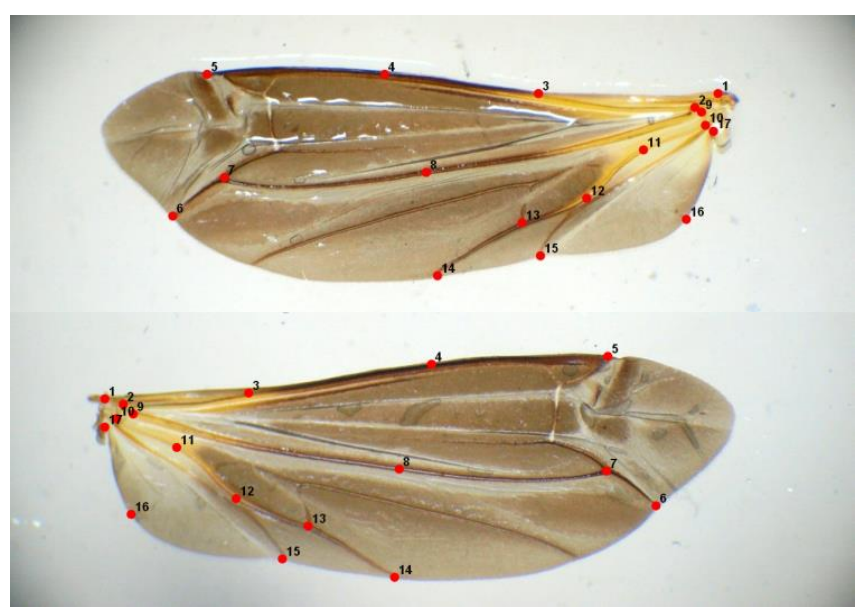

Fig. 1. Digitized image of the left and right wing showing the location of landmark points.

\section{Model Testing}

Digitalized images were subjected to landmark acquisition using tpsDig version 2.12 [13] to collect the $\mathrm{x}$, y coordinates of each landmark within the wing structure. Thin-plate spline deformation grids were produced to visualize the wing shape differences between male and female coconut hispid beetle. The thin-plate spline technique [4] consisted in fitting an interpolating function to the landmark coordinates of each specimen against the reference configuration so that all homologous landmarks coincide. The projection of the superimposed specimens onto the principal warps produced the partial-warp scores, which described their deviations from the reference configuration and that can be used as variables in subsequent multivariate statistical analyses [14].

\section{E. Statistical Analysis}

The relative warps analysis and computation of partial-warp scores were done using tpsRelw program version 1.46 [15] in order to yield information on the variation in local shape, which involved fitting and interpolation function to homologous landmarks for each specimen sample. From the result of the relative warps of the wing shape, histogram and box-and-whiskers plots were generated using the Paleontological Statistics (PAST) software version 2.17 [16]. The most informative warp scores (first and second relative warps) were subjected to Canonical Variance Analysis (CVA) to determine whether the shape of the inner wings differ significantly between the female and male population. Hotelling's pairwise comparisons (post-hoc) test which is a cross validation test using discriminant function analysis was then used to confirm or reject the hypothesis that two populations are morphologically distinct by classifying each specimen into one of the two groups (male or female). Variations between populations were considered statistically significant if the percentage of correctly classified specimen was greater than $75 \%$. The first and second relative warp scores of the pooled population data was subjected to
Kruskal-Wallis test in order to compare independent groups of sample data and, in this case, determined the significance of difference (at 0.05 level of significance) in the shape variations of wings [17]. All statistical analyses were performed in PAST software.

TABLE I: DESCRIPTION OF ANATOMICAL LANDMARK POINTS ASSIGNED ON BOTH LEFT AND RIGHT INNER WINGS RESPECTIVELY

\begin{tabular}{|c|c|}
\hline Landmark & Anatomical Description \\
\hline 1 & Proximal end of the Costa + Subcosta $(\mathrm{C}+\mathrm{Sc})$ \\
\hline 2 & Proximal end of the Radius \\
\hline 3 & $\begin{array}{l}\text { Costa-subcosta and median proximal end of Radius } \\
\text { connection }\end{array}$ \\
\hline 4 & Median distal end of Radius \\
\hline 5 & Distal end of Radius (R) \\
\hline 6 & Distal end of Media (M) \\
\hline 7 & Median distal end of Media \\
\hline 8 & Midpoint of Media \\
\hline 9 & Proximal end of the Radius + Media $(\mathrm{R}+\mathrm{M})$ \\
\hline 10 & $\begin{array}{l}\text { Proximal end of Cubitus and } 1^{\text {st }} \text { Anal vein connection } \\
(\mathrm{Cu}+\mathrm{A})\end{array}$ \\
\hline 11 & Proximal end of Cubitus \\
\hline 12 & Midpoint of Cubitus \\
\hline 13 & Median distal end of the Cubitus \\
\hline 14 & Distal end of the Cubitus \\
\hline 15 & Distal end of the $1^{\text {st }}$ Anal vein \\
\hline 16 & Distal end of the $2^{\text {nd }}$ Anal vein \\
\hline 17 & Proximal end of the $2^{\text {nd }}$ Anal vein \\
\hline
\end{tabular}

\section{RESULTS AND DISCUSSION}

Following a series of analysis made in the left and right inner wings of coconut hispid beetle (Brontispa longissima), it was found out that there was a shape variation between the female and male inner wings, consequently suggesting the presence of sexual dimorphism. The results of relative warp analysis on the left and right inner wings of the pooled population located at three different sampling locations showed at most 5 significant relative warps which defined the wing shape variation in both male and female population (Fig. 2 ). It can be observed clearly that the left and right wings for male and female population differed distinctively from each other as they yielded different shapes as presented by the negative and positive warps. The result of histogram and box-and-whiskers plot displayed a multimodal variation in the mode of distributions of wing shape and the mean values of left wing were close to the mean value of the right wing of one population described indicating a high degree of intrapopulation variation. In addition, the mean values of one population varied significantly to the mean values of the other population indicating a high degree of interpopulation variation in the beetle. As described in Table II-Table IV, majority of the variations in B. longissima wing shape morphology were found in the apical and basal region of the wing. Observable variations were based on the location of landmark points within the wing's structure.

Another tool used in this study is discriminant analysis that supplements the results obtained in the relative warp analysis for the presence of sexual dimorphism in coconut hispid beetle based on its wing shape. The visual result of the analysis is shown in a form of histogram (Fig. 3).

The histogram shows the difference between the shape of female and male's left and right inner wings in each of the population. Based on the graphs, they positively show that 
sexual dimorphism is an evident in all population of $B$. longissima from three different locations though there having been slight overlaps. The presence of the gap between the two components in right wing samples from San Vicente, Butuan
City, exhibits the greatest sexual dimorphism among them all. The farther the components are from each other, the greater the difference is in the shape of the wings.
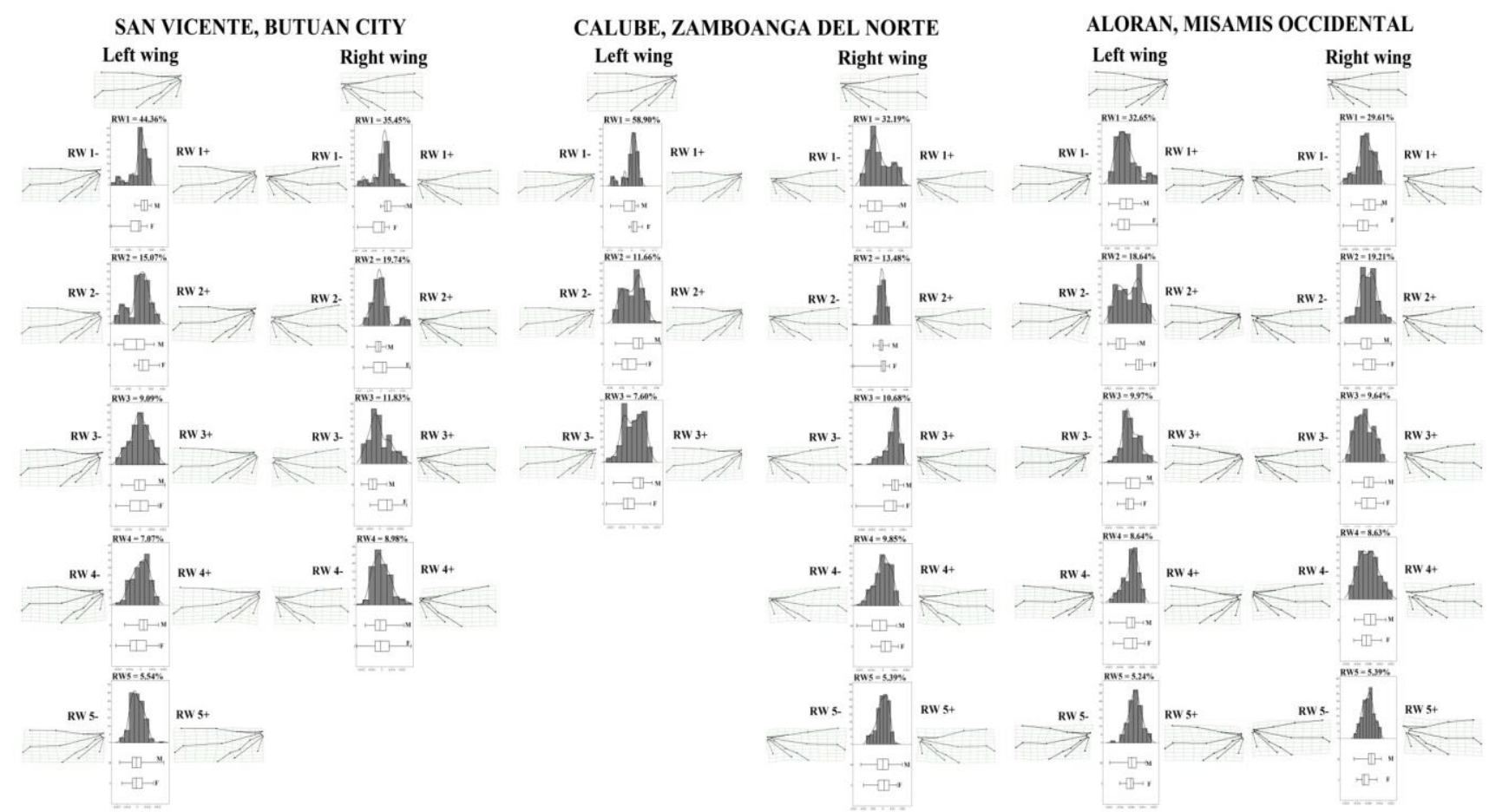

Fig. 2. Summary of the landmark based geometric morphometric analysis showing the consensus morphology (uppermost panels) and the variation in the shape of left and right inner wings between female and male populations of coconut hispid beetle (B. longissima) collected from different locations (Aloran, Misamis Occidental, Calube, Zamboanga del Norte and San Vicente, Butuan City) explained by each of the significant relative warps. Legend: F = female; M $=$ male.

TABLE II: VARIATION IN THE LANDMARK's POSITION WITHIN THE LEFT AND RIGHT INNER WINGS BETWEEN MALE AND FEMALE POPULATION SAMPLED AT ALORAN, MISAMIS OCCIDENTAL AS DEFINED BY EACH OF THE SIGNIFICANT RELATIVE WARPS

\begin{tabular}{|c|c|c|c|}
\hline \multicolumn{2}{|r|}{ LEFT WING } & \multicolumn{2}{|r|}{ RIGHT WING } \\
\hline RW1 & $\begin{array}{l}\text { Variation found in the apical and basal region } \\
\text { of the wing. The distance of the landmark at the } \\
\mathrm{C}+\mathrm{Sc} \text { and the median proximal end of the radius } \\
\text { connection is farther in females than in males. }\end{array}$ & RW1 & $\begin{array}{l}\text { Variation in the apical and basal region of the wing. } \\
\text { The distance of the landmark at the beginning of media } \\
\text { and the junction between } \mathrm{Cu} \text { and anal vein is farther in } \\
\text { females compared to males. }\end{array}$ \\
\hline RW2 & $\begin{array}{l}\text { Variation in the apical and basal region of the } \\
\text { wing. The landmark at the distal end of the radius } \\
\text { is farther in females than in males. In males, the } \\
\text { landmark at the junction of } \mathrm{Cu} \text { and } 1^{\text {st }} \text { anal vein is } \\
\text { farther compared to females. }\end{array}$ & RW2 & $\begin{array}{l}\text { The distance of the landmark at the distal end of the } \\
\text { media is farther in females than in males. In males, the } \\
\text { position of the landmark at the beginning of the } \\
\text { costa-subcosta is located superior compared to females. }\end{array}$ \\
\hline RW3 & $\begin{array}{l}\text { In males, the distance of the landmark at the } \\
\text { median and distal of the radius is farther compared } \\
\text { to females. }\end{array}$ & RW3 & $\begin{array}{l}\text { Variation in the apical and basal region of the wing. } \\
\text { The landmark at the distal end of the anal veins, cubitus } \\
\text { and media is farther in males than in females. }\end{array}$ \\
\hline RW4 & $\begin{array}{l}\text { Variation in the apical and basal region of the } \\
\text { wing. The distance of landmark at the distal end of } \\
\text { radius is farther in females than in males. The } \\
\text { position of landmarks in cubitus and anal veins is } \\
\text { located farther in females compared to males. }\end{array}$ & RW4 & $\begin{array}{l}\text { The landmark at the proximal end of the } 2^{\text {nd }} \text { anal } \\
\text { vein and the juncture of } \mathrm{Cu}+\mathrm{M} \text { is located farther in } \\
\text { males than in females. }\end{array}$ \\
\hline RW5 & $\begin{array}{l}\text { The distance of the landmark at the midpoint of } \\
\text { media is farther in females than in males. In males, } \\
\text { the distance of the proximal and distal end of the } \\
2^{\text {nd }} \text { anal vein is farther compared to females. }\end{array}$ & RW5 & $\begin{array}{l}\text { The distance of the landmark at the } \mathrm{C}+\mathrm{Sc} \text { and the } \\
\text { proximal end of the radius is shorter in females than in } \\
\text { males. Landmark located between the proximal and } \\
\text { distal end of the cubitus is farther in females compared } \\
\text { to males. }\end{array}$ \\
\hline
\end{tabular}

In contrast, there were instances wherein sexual dimorphism was probable even if overlapping occurred in the histogram. This can be explained by the values given in the discrimination score table where the percentage of correctly classified items was given (Table V). This percentage shows how correctly female wings were classified as female and how correctly male wings were classified as males. If the discriminant analysis was efficient for a set of data, the classification table of correct and incorrect estimates would yield a high percentage. In the given set of data, the result showed that in left wing for the different populations, 95\%, $87.78 \%$ and $91.67 \%$ were classified correctly in Aloran, Misamis Occidental, Calube, Zamboanga del Norte and San Vicente, Butuan City respectively. On the other hand, the results for the right wing show that $88.89 \%, 77.78 \%$ and $100 \%$ were classified correctly for the three locations 
respectively. It is observable that there is a number of mistakenly classified male and females for Calube, Zamboanga del Norte right wing. But, despite this discrepancy, it is still safe to say that the degree of shape variation in the right primary wing was relatively high since the minimum percentage of correctly classified items should be $75 \%$ for it to be considered significant.

TABLE III: VARIATION IN THE LANDMARK's POSITION WITHIN THE LEFT AND RIGHT INNER WINGS BETWEEN MALE AND FEMALE POPULATION SAMPLED AT CALUBe, ZAMBOANGA DEL NORTE AS DEFINED By EACH OF THE SigNIFICANT RELATIVE WARPS

\begin{tabular}{|c|c|c|c|}
\hline \multicolumn{2}{|r|}{ LEFT WING } & \multicolumn{2}{|r|}{ RIGHT WING } \\
\hline RW1 & $\begin{array}{l}\text { The distance of the landmark point between the } \\
\text { distal end and beginning of media is farther in } \\
\text { females than in males. }\end{array}$ & RW1 & $\begin{array}{l}\text { The distance of the landmark points located at the } \\
\text { cubitus vein is farther in females than in males. }\end{array}$ \\
\hline RW2 & $\begin{array}{l}\text { Variation at the apical and basal region of the } \\
\text { wing. The distance of the landmark point at the } \\
\text { junction of costa-subcosta and radius is farther in } \\
\text { females than in males. }\end{array}$ & RW2 & $\begin{array}{l}\text { The distance of the landmark point between the } \\
\text { midpoint and proximal end of the cubitus vein is farther } \\
\text { in females than in males. }\end{array}$ \\
\hline \multirow[t]{3}{*}{ RW3 } & $\begin{array}{l}\text { The distance of the landmark points located at the } \\
\text { radius, media, cubitus and anal veins are farther in } \\
\text { females compared to males. }\end{array}$ & RW3 & $\begin{array}{l}\text { The distance of the landmark point at the proximal end } \\
\text { of radius and distal end of the } 2^{\text {nd }} \text { anal vein is farther in } \\
\text { males than in females. }\end{array}$ \\
\hline & & RW4 & $\begin{array}{l}\text { Variation at the apical and basal region of the wing. The } \\
\text { distance of the landmark point at the median distal end } \\
\text { of the radius and distal end of the cubitus is farther in } \\
\text { females than in males. }\end{array}$ \\
\hline & & RW5 & $\begin{array}{l}\text { The distance of the landmark point located on the } \\
\text { junction of } \mathrm{C}+\mathrm{Sc} \text { and radius is farther in females than in } \\
\text { males. In males, the distal end of the radius is farther } \\
\text { compared to females. }\end{array}$ \\
\hline
\end{tabular}

TABLE IV: VARIATION IN THE LANDMARK'S POSITION WITHIN THE LEFT AND RIGHT INNER WINGS BETWEEN MALE AND FEMALE POPULATION SAMPLED AT SAN Vicente, Butuan City as Defined by EaCH OF the Significant RELATIVE WARPS

\begin{tabular}{|c|c|c|c|}
\hline \multicolumn{2}{|r|}{ LEFT WING } & \multirow{2}{*}{\multicolumn{2}{|c|}{$\begin{array}{l}\text { RIGHT WING } \\
\text { The distance of the landmark point at the beginning of } 2^{\text {nd }} \text { anal vein and } \\
\text { distal end of cubitus is farther in female than in males. }\end{array}$}} \\
\hline R1 & $\begin{array}{l}\text { Variation at the apical and basal region of the wing. The } \\
\text { distance of the landmark point at the median distal end of the } \\
\text { radius and distal end of cubitus and anal vein is farther in } \\
\text { females than in males. }\end{array}$ & & \\
\hline W2 & $\begin{array}{l}\text { In males, the distance of the landmark point between the } \\
\text { midpoint of radius and junction of } \mathrm{C}+\mathrm{Sc} \text { and } \mathrm{R} \text { is farther in } \\
\text { females than in males. }\end{array}$ & RW2 & $\begin{array}{l}\text { The landmark point at the midpoint of media is farther in males than in } \\
\text { females. Males have slightly wider distance of juncture between radius } \\
\text { and cubitus. }\end{array}$ \\
\hline W3 & $\begin{array}{l}\text { In females, the landmark point at the beginning of media, } \\
\text { cubitus and anal veins is located slightly higher (shifted towards } \\
\text { the apex of the wing). }\end{array}$ & RW3 & $\begin{array}{l}\text { Variation at the apical and basal region of the wing. The distance of the } \\
\text { landmark point from the junction of } \mathrm{C}+\mathrm{Sc} \text { and radius to the distal end is } \\
\text { farther in females than in males. In males, the juncture of } \mathrm{Cu}+\mathrm{A} \text { is } \\
\text { narrower compared to females. }\end{array}$ \\
\hline W4 & $\begin{array}{l}\text { The distance of the landmark point at the median distal end of } \\
\text { the media and cubitus is farther in females than in males. }\end{array}$ & RW4 & $\begin{array}{l}\text { The distance of the landmark point at the proximal and distal end of the } \\
\text { second anal vein is farther in females than in males. Juncture of } \mathrm{C}+\mathrm{Sc} \\
\text { and beginning of radius is narrower in males compared to females. }\end{array}$ \\
\hline $\begin{array}{l}\mathrm{R} \\
\mathrm{W} 5\end{array}$ & $\begin{array}{l}\text { The distance of the landmark point at the juncture of } \\
\text { costa-subcosta and radius is farther in males than in females. }\end{array}$ & & \\
\hline
\end{tabular}

The CVA scatter plot (Fig. 4) shows the distribution of female and male coconut hispid beetle population based on the landmark analysis on its left and right inner wings. Comparing the shapes of left and right wings based from pooled and the most important scores, the generated CVA scatter plot and scores revealed a randomly distributed wing shape distribution suggesting high intrapopulational variation The scatter plot also presents distinct difference between male and female wing shape among different locations which then display a high possibility of interpopulational variation. It is important to note however, that the result of the non-parametric Kruskal-Wallis test $\left(p=1.694^{-46}<0.05\right.$ and $p$ $\left.=7.811^{-17}<0.05\right)$ for pooled left wing and right wing respectively, showed that there were significant differences between the medians of at least two populations. Results of the Bonferroni corrected Mann-Whitney pairwise comparison of the most significant warp scores (first and second) of the wing shape for all populations in different locations are shown in Table VI. Pairwise comparisons showed that for the left wing, the male and female Aloran population ware significantly different from the other population while for the right wing the female San Vicente population was significantly different from all other populations.

It can be seen from the results obtained from landmark based analysis of the inner wings that a variation existed in the shape of left and right wings between female and male sexes. The overall landmarks located within the structure of the wings can both serve as criteria for determining wing sexual dimorphism. A significant wing shape variation has been observed between female and male Drosophila melanogaster [18], in Chilo suppressalis [19], in Synneuria sp. [2] and in Schirpophaga innotata [1]. In the last few decades, a number of hypotheses have been proposed to explain sexual dimorphism in insects [20], [21]. One of the most commonly used is the hypothesis indicating the connection between sexual selection versus natural selection and environmental variation [22] although male-male competition and the segregation of sexes due to limited resources [23] have produced notable selective differentiation. 
TABLE V: RECLASSIFICATION OF THE COCONUT HISPID BEETLE (BRONTISPA LONGISSIMA) INTO FEMALE OR MALE BASED ON THE LANDMARK ANALYSIS OF THE WINGS

\begin{tabular}{|c|c|c|c|c|}
\hline LEFT WING & & Female & Male & Total \\
\hline \multirow{3}{*}{$\begin{array}{l}\text { Aloran, Misamis } \\
\text { Occidental }\end{array}$} & Female & 88 & 2 & 90 \\
\hline & Male & 6 & 84 & 90 \\
\hline & $\begin{array}{r}\% \text { Correctly } \\
\text { Classified }\end{array}$ & & & $95.00 \%$ \\
\hline \multirow{3}{*}{$\begin{array}{l}\text { Calube, } \\
\text { Zamboanga } \\
\text { Norte }\end{array}$} & Female & 79 & 11 & 90 \\
\hline & Male & 10 & 80 & 90 \\
\hline & $\begin{array}{r}\% \text { Correctly } \\
\text { Classified }\end{array}$ & & & $\mathbf{8 7 . 7 8 \%}$ \\
\hline \multirow[t]{3}{*}{$\begin{array}{l}\text { SanVicente, } \\
\text { Butuan City }\end{array}$} & Female & 75 & 15 & 90 \\
\hline & Male & 1 & 89 & 90 \\
\hline & $\begin{array}{r}\% \text { Correctly } \\
\text { Classified }\end{array}$ & & & $91.67 \%$ \\
\hline \multicolumn{5}{|l|}{ RIGHT WING } \\
\hline \multirow[t]{3}{*}{$\begin{array}{l}\text { Aloran, Misamis } \\
\text { Occidental }\end{array}$} & Female & 83 & 7 & 90 \\
\hline & Male & 13 & 77 & 90 \\
\hline & $\begin{array}{r}\% \text { Correctly } \\
\text { Classified }\end{array}$ & & & $\mathbf{8 8 . 8 9 \%}$ \\
\hline \multirow{3}{*}{$\begin{array}{l}\text { Calube, } \\
\text { Zamboanga del } \\
\text { Norte }\end{array}$} & Female & 73 & 17 & 90 \\
\hline & Male & 23 & 67 & 90 \\
\hline & $\begin{array}{r}\% \text { Correctly } \\
\text { Classified }\end{array}$ & & & $\mathbf{7 7 . 7 8 \%}$ \\
\hline \multirow[t]{3}{*}{$\begin{array}{l}\text { SanVicente, } \\
\text { Butuan City }\end{array}$} & Female & 90 & 0 & 90 \\
\hline & Male & 0 & 90 & 90 \\
\hline & $\begin{array}{r}\% \text { Correctly } \\
\text { Classified } \\
\end{array}$ & & & $100 \%$ \\
\hline
\end{tabular}

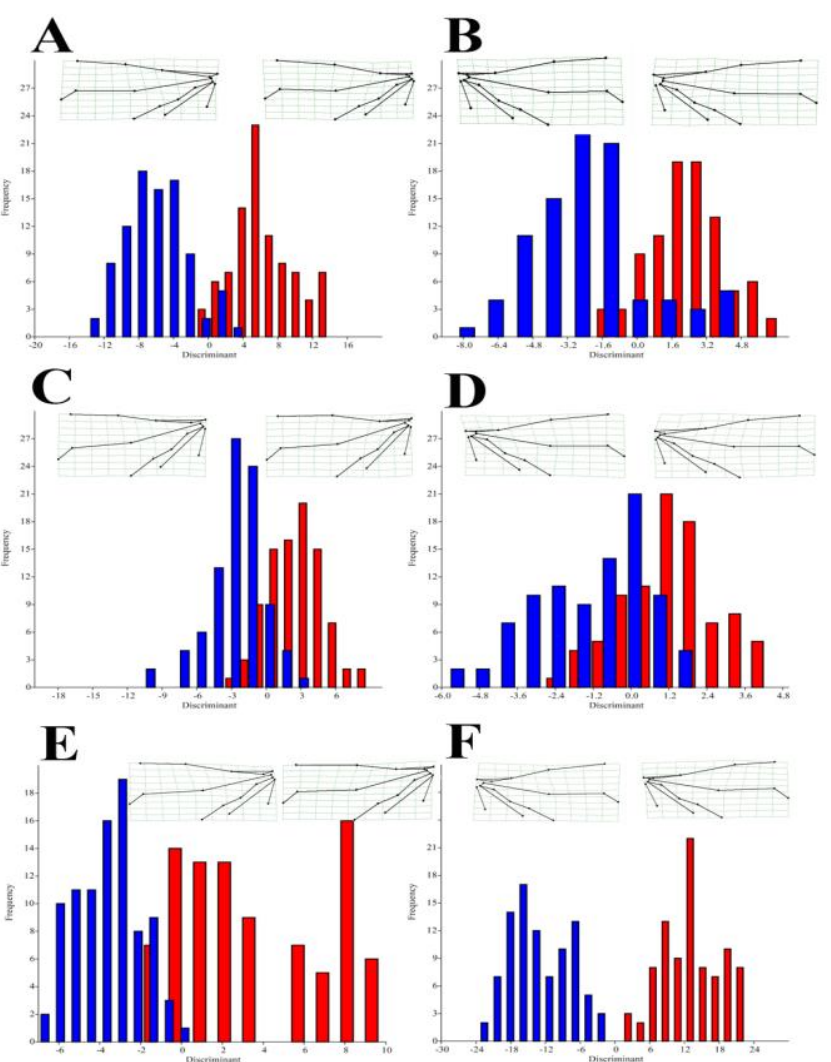

Fig. 3. Histogram showing the variation in the left and right inner wing shape of the male (blue) and female (red) species of B. longissima between (A) the left wing (B) the right wing from Aloran, Misamis, (C) the left wing (D) the right wing from Calube, Zamboanga del Norte and (E) the left wing (F) the right wing from San Vicente, Butuan City.

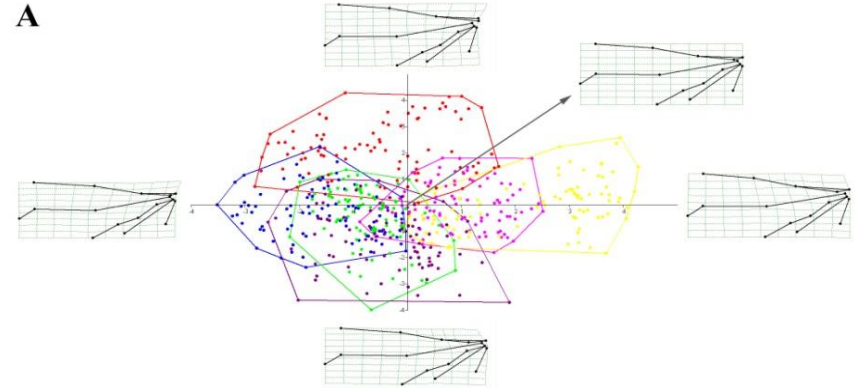

B

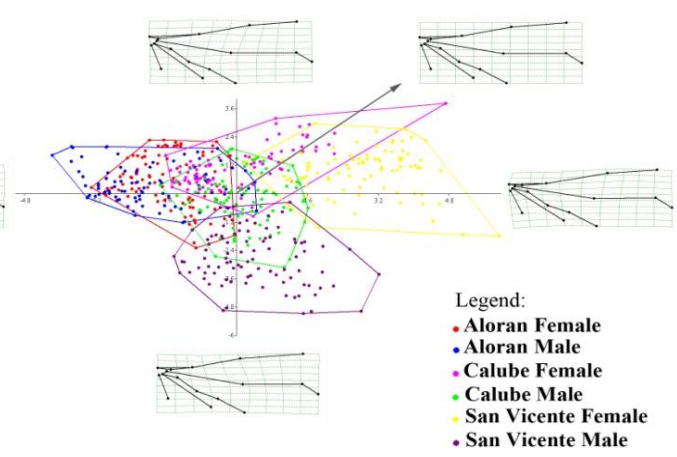

Fig. 4. CVA scatter plot showing the distribution of wing shapes (A) left wing (B) right wing of samples from different provinces of the Philippines based on landmark based geometric morphometric analysis with corresponding shape of each axis and the mean shape indicated by the arrow. Results of MANOVA test in wing shape: Wilk's Lambda $=0.0961, \mathrm{dfl}=25$, df $2=1970, F=43.51$, and $\mathrm{p}($ same $)=6.553^{-248}$.

TABLE VI: RESULT OF KRUSKAL-WALLIS TEST ON WING SHAPE IN DIFFERENT LOCATIONS BASED ON THE FIRST AND SECOND RELATIVE WARP SCORE. MANN-WHITNEY PAIRWISE COMPARISON (BONFERRONI CORRECTED) OF THE WING SHAPE (0.05 LEVEL OF SiGNIFICANCE)

\begin{tabular}{|c|c|c|c|c|c|c|}
\hline \multicolumn{7}{|c|}{ Left Wing } \\
\hline & $\mathrm{A}(\mathrm{F})$ & $\mathrm{A}(\mathrm{M})$ & $\mathrm{C}(\mathrm{F})$ & $\mathrm{C}(\mathrm{M})$ & SV $(F)$ & SV (M) \\
\hline $\mathrm{A}(\mathrm{F})$ & - & & & & & \\
\hline $\mathrm{A}(\mathrm{M})$ & $2.57^{-04}$ & - & & & & \\
\hline $\mathrm{C}(\mathrm{F})$ & $2.38^{-15}$ & $2.09^{-05}$ & - & & & \\
\hline $\mathrm{C}(\mathrm{M})$ & $1.56^{-07}$ & $8.63^{-04}$ & 1 & - & & \\
\hline & & & & $1.81^{-0}$ & & \\
\hline $\mathrm{SV}(\mathrm{F})$ & $2.47^{-34}$ & $6.88^{-34}$ & $1.07^{-11}$ & 8 & - & \\
\hline SV (M) & $1.40^{-10}$ & $1.95^{-05}$ & 1 & 1 & $3.86^{-13}$ & - \\
\hline \multicolumn{7}{|c|}{ Right Wing } \\
\hline $\mathrm{A}(\mathrm{F})$ & ${ }^{-}$ & & & & & \\
\hline $\mathrm{A}(\mathrm{M})$ & 3 & - & & & & \\
\hline $\mathrm{C}(\mathrm{F})$ & 1 & $2.11^{-05}$ & - & & & \\
\hline $\mathrm{C}(\mathrm{M})$ & 1 & $1.245^{-05}$ & 1 & - & & \\
\hline SV (F) & $3.21^{-07}$ & $3.66^{-14}$ & $1.49^{-05}$ & $\begin{array}{c}7.65^{-0} \\
7\end{array}$ & - & \\
\hline SV (M) & 1 & $\begin{array}{c}0.0913 \\
4\end{array}$ & $\begin{array}{c}0.314 \\
7\end{array}$ & 1 & $5.28^{-09}$ & - \\
\hline
\end{tabular}

Individual variation in shape which is strongly dependent on environmental conditions is frequently argued [24]. The environment of the living organisms, with rather few exceptions, is spatially and temporarily diverse resulting to a continuous movement of organisms to colonize empty habitat and to offset the inevitable local extinctions. [19] reported in their study that environmental factors (geographic condition and host type) were considered in asserting that the phenotypes of an individual is the result of the interaction between genotype and environment showing that the most geographically distant population are also the most morphologically varied.

Another suggested factor that possibly explains sexual dimorphism in insects is the variation in the functions 
performed between sexes [25]. In insects, flight is the most likely considered selective pressure influencing the evolution of sexual shape dimorphism in the wing. Since characteristic flight behaviour in females is to search for host plants for oviposition sites and in males for the nuptial flight, territoriality and search mating opportunities, flight requirements and optimal wing shapes may differ for sexes. Therefore, the selection would act on wing shape to optimize flight characteristics [26].

\section{CONCLUSION}

Analysis of the wing shape morphology of coconut hispid beetle (Brontispa longissima) found variation between the female and male inner wings, consequently suggesting the presence of sexual dimorphism. This study has demonstrated the effectiveness of geometric morphometric in describing morphological variation within and between populations of organisms.

\section{ACKNOWLEDGMENT}

The senior author would like to thank the DOST-SEI (ASTHRDP) for the scholarship grant. Acknowledgement is also due to Dr. Mark Anthony Torres, Mr. Muhmin Michael Manting and Ms. Jade Marie Sobrepeña for the technical assistance.

\section{REFERENCES}

[1] Q. B. Albutra, M. A. J. Torres, and C. G. Demayo, "Outline and landmark based geometric morphometric analysis in describing sexual dimorphism in wings of the white stem borer (Schirpophaga innotata Walker)," Animal Biology and Animal Husbandry, vol. 4, no. 1, pp. 5-13, 2012.

[2] H. A. Benitez, L. E. Parra, E. Sepulveda, and M. J. Sanzana, "Geometric perspectives of sexual dimorphism in the wing shape of Lepidoptera: the case of Synneuria sp. (Lepidoptera: Geometridae)," Journal of Entomological Research Society, vol. 13, no.1, pp. 53-60, 2011.

[3] M. Koehl, "When does morphology matter?" Annual Review of Ecology and Systematics, vol. 27, pp. 501-542, 1996.

[4] F. L. Bookstein, Morphometric Tools for Landmark Data: Geometry and Biology, Cambridge: Cambridge University Press, 1991.

[5] F. J. Rohlf and L. F. Marcus, "A revolution in morphometrics, Trends Ecology \& Evolution,” vol. 8, no. 4, pp. 129-132, 1993.

[6] D. Adams and D. J. Funk, "Morphometric inferences on sibling species and sexual dimorphism in Neochlamisus bebbianae leaf beetles: Multivariate applications of the thin-plate spline," Systematic Biology, vol. 46, no. 1, pp. 180-194, 1997.

[7] D. Adams and F. J. Rohlf, "Ecological character displacement in Pletodon: biomechanical differences found from a geometric morphometric study," in Proc. the National Academy of Sciences of the United States of America, vol. 97, pp. 4106-4111, 2000.

[8] H. Benítez, M. Vidal, R. Briones, and V. Jerez, "Sexual dimorphism and population morphological variation of Ceroglossus chilensis (Eschscholtz) (Coleoptera, Carabidae)," Journal of the Entomological Research Society, vol. 12, no. 2, pp. 87-95, 2010.

[9] S. Nakamura, K. Konishi, and K. Takasu, "Invasion of the coconut hispine beetle, Brontispa longissima: Current situation and control measures in Southeast Asia," in Proc. International workshop on development of database (APASD) for biological invasion, vol. 3, pp. $1-9,2006$.

[10] B. G. B. Belleza and C. G. Demayo, "Describing compartmentalization in the hind wing of the hispid beetle Brontispa longissima," European Journal of Zoological Research, vol. 3, no. 1, pp. 13-18, 2014.
[11] D. C. Adams, "Methods for shape analysis of landmark data from the articulated structures," Evolutionary Ecology Research, vol. 1, pp. 959-970, 1999.

[12] F. J. Rohlf, "Tps Utility program version 1.44," Ecology and Evolution, State University of New York at Story Brook, 2009.

[13] F. J. Rohlf, "TPSDig version 2.12," Department of Ecology and Evolution, State University of New York at story Brook, New York, 2008a.

[14] F. J. Rohlf, "Thin-plate spline, digitize landmarks and outlines, version 1.20," Dept Ecol. \& Evol., St. Univ. New York, Stony Brook, New York, 2004.

[15] F. J. Rohlf, "TPSRelw version 1.46," Department of Ecology and Evolution, State University of New York at Story Brook, New York, $2008 \mathrm{~b}$.

[16] Ø. Hammer, D. A. T. Harper, and P. D. Ryan, "PAST version 1.91: Paleontological Statistical Software package for education and data analysis," Paleontologia Electronica, vol. 4, no. 1, pp. 9, 2001.

[17] O. S. Anies, M. A. J. Torres, M. M. Manting, and C. G. Demayo, "Landmark-based geometric morphometrics in describing facial shape of the sama-banguingui tribe from the Philippines," Journal of Medical and Bioengineering, vol. 2, pp. 2, 2013.

[18] J. Kunkel and B. R. Bettencourt. (2001). Transformer-2 controls subtle sexually dimorphic features in Drosophila melanogaster wing development. [Online]. Available: http://bcrc.bio.umass.edu/flyclub/kunkel/kb

[19] R. Zahiri, A. Sarafrazi, L. Salehi, and G. J. Kunkel, "A geometric morphometric study on the populations of Rice Stem Borer, Chilo suppressalis Walker (Lepidoptera: Cambridae) in Northern Iran," Zoology in the Middle East, vol. 38, pp. 70-84, 2006.

[20] S. E. Walker and A. L. Rypstra, "Sexual dimorphism in functional response and trophic morphology in Rabidosa rabida (Aranae: Lycosidae)," American Midland Naturalist, vol. 146, no. 1, pp. 161-170, 2001.

[21] T. Esperk, T. Tammaru, S. Nylin, and T. Teder, "Achieving high sexual size dimorphism in insects: females add instars," Ecological Entomology, vol. 32, pp. 243-256, 2007.

[22] A. P. Moller and C. Zamora-Muñoz, "Antennal asymmetry and sexual selection in a cerambycid beetle," Animal Behaviour, vol. 54, pp. 1509-1515, 1997

[23] Y. Saito and K. Mori, "Where does male-to-male aggression compromise cooperation?" Population Ecology, vol. 47, pp. 159-166, 2005.

[24] H. Tatsuta, K. Mizota, and S. I. Akimoto, "Relationship between size and shape in the sexually dimorphic beetle Prosopocoilus inclinatus (Coleoptera: Lucanidae)," Biological Journal of the Linnean Society, vol. 81, pp. 219-233, 2004.

[25] A. J. McLachlan, "Sexual dimorphism in Midges: strategies for flight in the rain-pool dweller Chironomus imicola (Diptera Chironomidae)," Journal of Animal Ecology, vol. 55, no. 1, pp 261-267, 1986.

[26] P. J. DeVries, C. M. Penz, and R. I. Hill, "Vertical distribution, flight behaviour and evolution of wing morphology in Morpho butterflies," Journal of Animal Ecology, vol. 76, pp. 417-435, 2010.

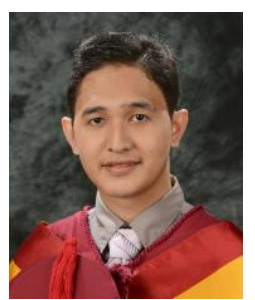

Bryan George D. Belleza is currently pursuing his degree of masters of science in biology at the MSUIligan Institute of Technology, Iligan City, Philippines.

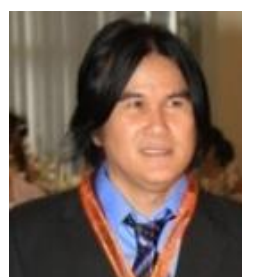

Cesar G. Demayo is currently a professor and the chairman of the Department of Biological Sciences, College of Science and Mathematics, MSU-Iligan Institute of Technology, Iligan City, Philippines. His researches include environmental toxicology, biodiversity and genetics. He is an active member of the Philippine Society for the Study of Nature and the Pest Management Council of the Philippines. 